\title{
Pittosporum obovatum
}

\author{
Assessment by: Gemmill, C. et al.
}

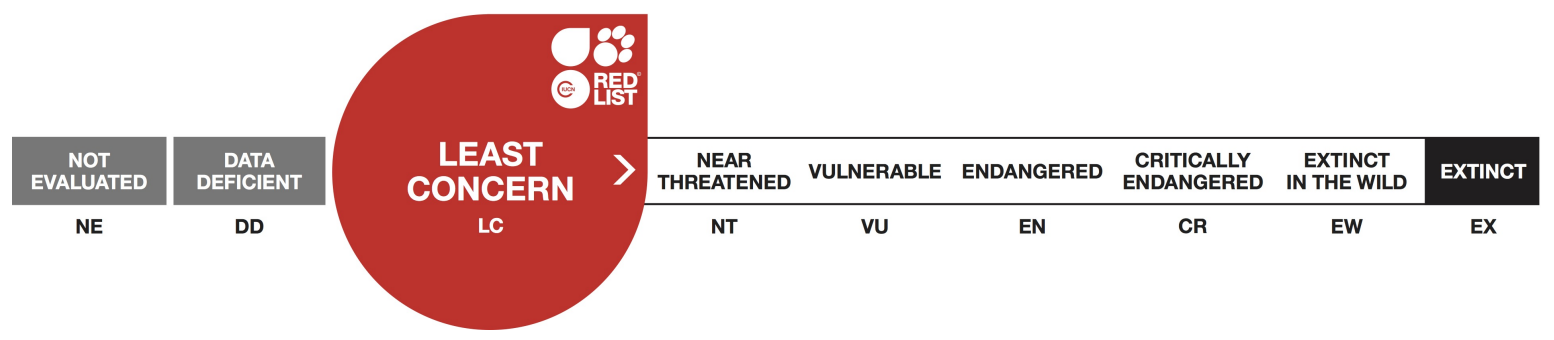

View on www.iucnredlist.org

Short citation: Gemmill, C. et al. 2017. Pittosporum obovatum. The IUCN Red List of Threatened Species 2017: e.T82948190A82951862. http://dx.doi.org/10.2305/IUCN.UK.20173.RLTS.T82948190A82951862.en [see full citation at end]

Copyright: (C 2017 International Union for Conservation of Nature and Natural Resources Reproduction of this publication for educational or other non-commercial purposes is authorized without prior written permission from the copyright holder provided the source is fully acknowledged.

Reproduction of this publication for resale, reposting or other commercial purposes is prohibited without prior written permission from the copyright holder. For further details see Terms of Use.

The IUCN Red List of Threatened Species ${ }^{T M}$ is produced and managed by the IUCN Global Species Programme, the IUCN Species Survival Commission (SSC) and The IUCN Red List Partnership. The IUCN Red List Partners are: Arizona State University; BirdLife International; Botanic Gardens Conservation International; Conservation International; NatureServe; Royal Botanic Gardens, Kew; Sapienza University of Rome; Texas A\&M University; and Zoological Society of London.

If you see any errors or have any questions or suggestions on what is shown in this document, please provide us with feedback so that we can correct or extend the information provided. 


\section{Taxonomy}

\begin{tabular}{|c|c|c|c|c|}
\hline Kingdom & Phylum & Class & Order & Family \\
\hline Plantae & Tracheophyta & Magnoliopsida & Rosales & Pittosporaceae \\
\hline
\end{tabular}

Taxon Name: Pittosporum obovatum Guillaumin

\section{Taxonomic Source(s):}

Tirel, Ch. and Veillon, J.-M. 2002. Flore de la Nouvelle-Calédonie, tome 24. Pittosporaceae. Museum d'Histoire Naturelle, Paris.

\section{Assessment Information}

Red List Category \& Criteria: $\quad$ Least Concern ver 3.1

Year Published: 2017

Date Assessed: July 24, 2015

\section{Justification:}

Pittosporum obovatum is an endemic small tree of New Caledonia, occurring only on îles Loyauté. Pittosporum obovatum occurs in dense forest and secondary open scrub on emerged coral formations. An abundant species, $P$. obovatum does not appear to be threatened in the short term thanks to it being adapted to growing in a stressed environment. As a consequence, $P$. obovatum is assessed as Least Concern (LC).

\section{Geographic Range}

\section{Range Description:}

Pittosporum obovatum is an endemic small tree of New Caledonia, occurring only on the Loyauté islands.

\section{Country Occurrence:}

Native: New Caledonia 


\section{Distribution Map}

\section{Pittosporum obovatum}
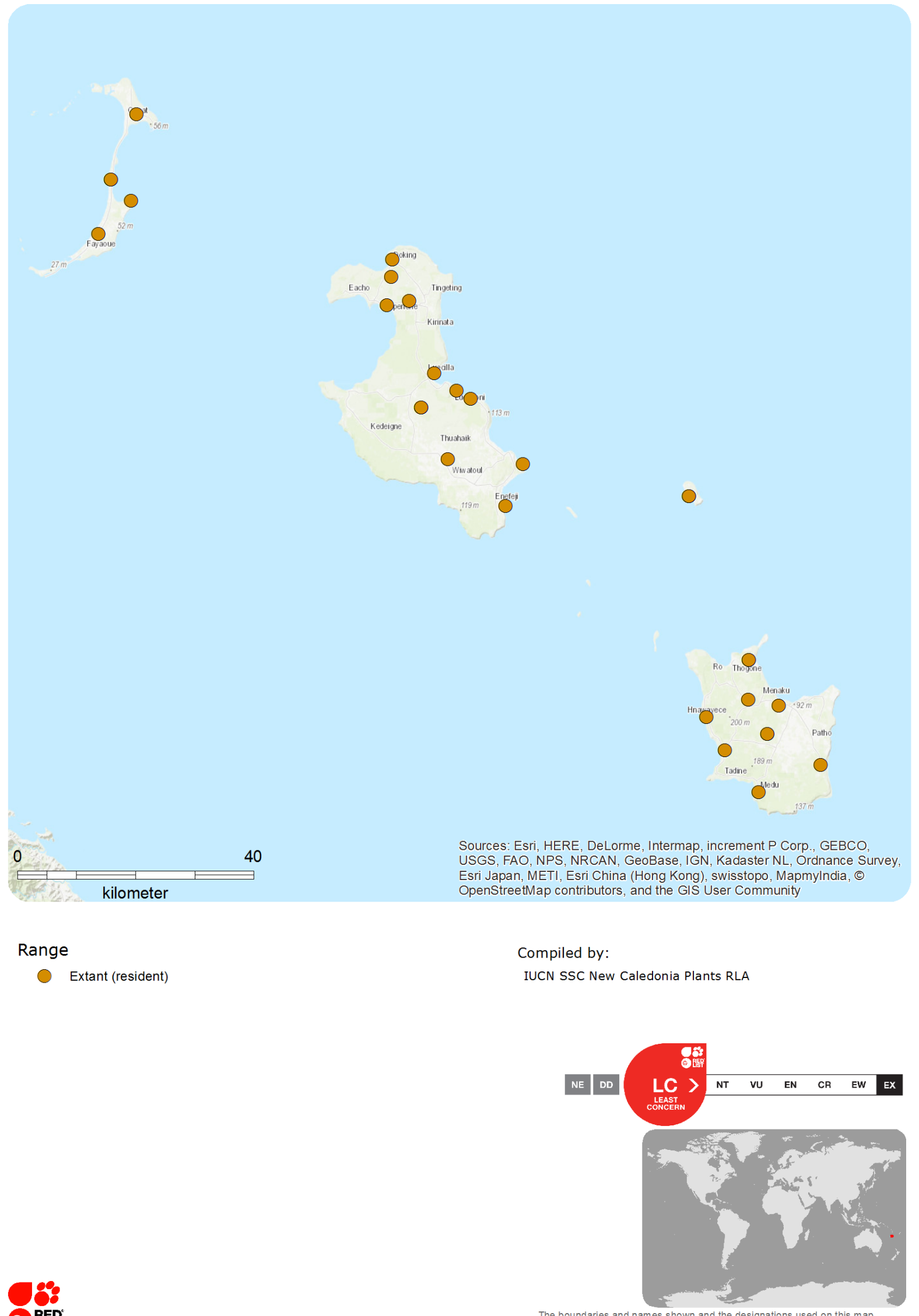


\section{Population}

Pittosporum obovatum is a relatively abundant species.

Current Population Trend: Stable

\section{Habitat and Ecology (see Appendix for additional information)}

Pittosporum obovatum occurs in dense forest and secondary open scrub on emerged coral formations.

Systems: Terrestrial

\section{Threats}

Pittosporum obovatum does not appear to be threatened at short term thanks to its growth in a stressed environment. In the long term, excessive impact of invasive species could be detrimental to this species.

\section{Conservation Actions (see Appendix for additional information)}

Pittosporum obovatum is not protected by any legislation and does not occur in any protected area.

\section{Credits}

Assessor(s): $\quad$ Gemmill, C., Veillon, J.-M., Amice, R., Cazé, H., Dumontet, V., Fleurot, D., Garnier, D., Gâteblé, G., Letocart, I., Letocart, D., Maggia, L. \& Pain, A.

Reviewer(s): $\quad$ Tanguy, V.

Facilitators(s) and Chanfreau, S.

Compiler(s): 


\section{Bibliography}

Endemia.nc. 2016. Faune et Flore de Nouvelle-Calédonie. Available at: http://www.endemia.nc.

IUCN. 2017. The IUCN Red List of Threatened Species. Version 2017-3. Available at: www.iucnredlist.org. (Accessed: 7 December 2017).

Tirel, Ch. and Veillon, J.-M. 2002. Flore de la Nouvelle-Calédonie, tome 24. Pittosporaceae. Museum d'Histoire Naturelle, Paris.

\section{Citation}

Gemmill, C., Veillon, J.-M., Amice, R., Cazé, H., Dumontet, V., Fleurot, D., Garnier, D., Gâteblé, G., Letocart, I., Letocart, D., Maggia, L. \& Pain, A. 2017. Pittosporum obovatum. The IUCN Red List of Threatened Species 2017: e.T82948190A82951862. http://dx.doi.org/10.2305/IUCN.UK.20173.RLTS.T82948190A82951862.en

\section{Disclaimer}

To make use of this information, please check the Terms of Use.

\section{External Resources}

For Images and External Links to Additional Information, please see the Red List website. 


\section{Appendix}

\section{Habitats}

(http://www.iucnredlist.org/technical-documents/classification-schemes)

\begin{tabular}{|c|c|c|c|}
\hline Habitat & Season & Suitability & $\begin{array}{l}\text { Major } \\
\text { Importance? }\end{array}$ \\
\hline 1. Forest -> 1.6. Forest - Subtropical/Tropical Moist Lowland & - & Suitable & - \\
\hline 3. Shrubland -> 3.6. Shrubland - Subtropical/Tropical Moist & - & Suitable & - \\
\hline
\end{tabular}

\section{Conservation Actions in Place}

(http://www.iucnredlist.org/technical-documents/classification-schemes)

\begin{tabular}{|l|}
\hline Conservation Actions in Place \\
\hline In-Place Land/Water Protection and Management \\
\hline Occur in at least one PA: No \\
\hline Invasive species control or prevention: No \\
\hline In-Place Species Management \\
\hline Successfully reintroduced or introduced beningly: No \\
\hline Subject to ex-situ conservation: No \\
\hline
\end{tabular}

\section{Additional Data Fields}

\begin{tabular}{|l|}
\hline Distribution \\
\hline Estimated area of occupancy (AOO) $\left(\mathrm{km}^{2}\right): 96$ \\
\hline Continuing decline in area of occupancy (AOO): No \\
\hline Extreme fluctuations in area of occupancy (AOO): No \\
\hline Estimated extent of occurrence (EOO) ( $\left.\mathrm{km}^{2}\right): 5853$ \\
\hline Continuing decline in extent of occurrence (EOO): No \\
\hline Extreme fluctuations in extent of occurrence (EOO): No \\
\hline Number of Locations: 6 \\
\hline Continuing decline in number of locations: No \\
\hline Extreme fluctuations in the number of locations: No \\
\hline Lower elevation limit (m): 10 \\
\hline Upper elevation limit (m): 10 \\
\hline
\end{tabular}




\section{Population}

Continuing decline of mature individuals: No

Extreme fluctuations: No

Population severely fragmented: No

No. of subpopulations: 6

Extreme fluctuations in subpopulations: No

Habitats and Ecology

Continuing decline in area, extent and/or quality of habitat: No

Generation Length (years): 0 


\section{The IUCN Red List Partnership}

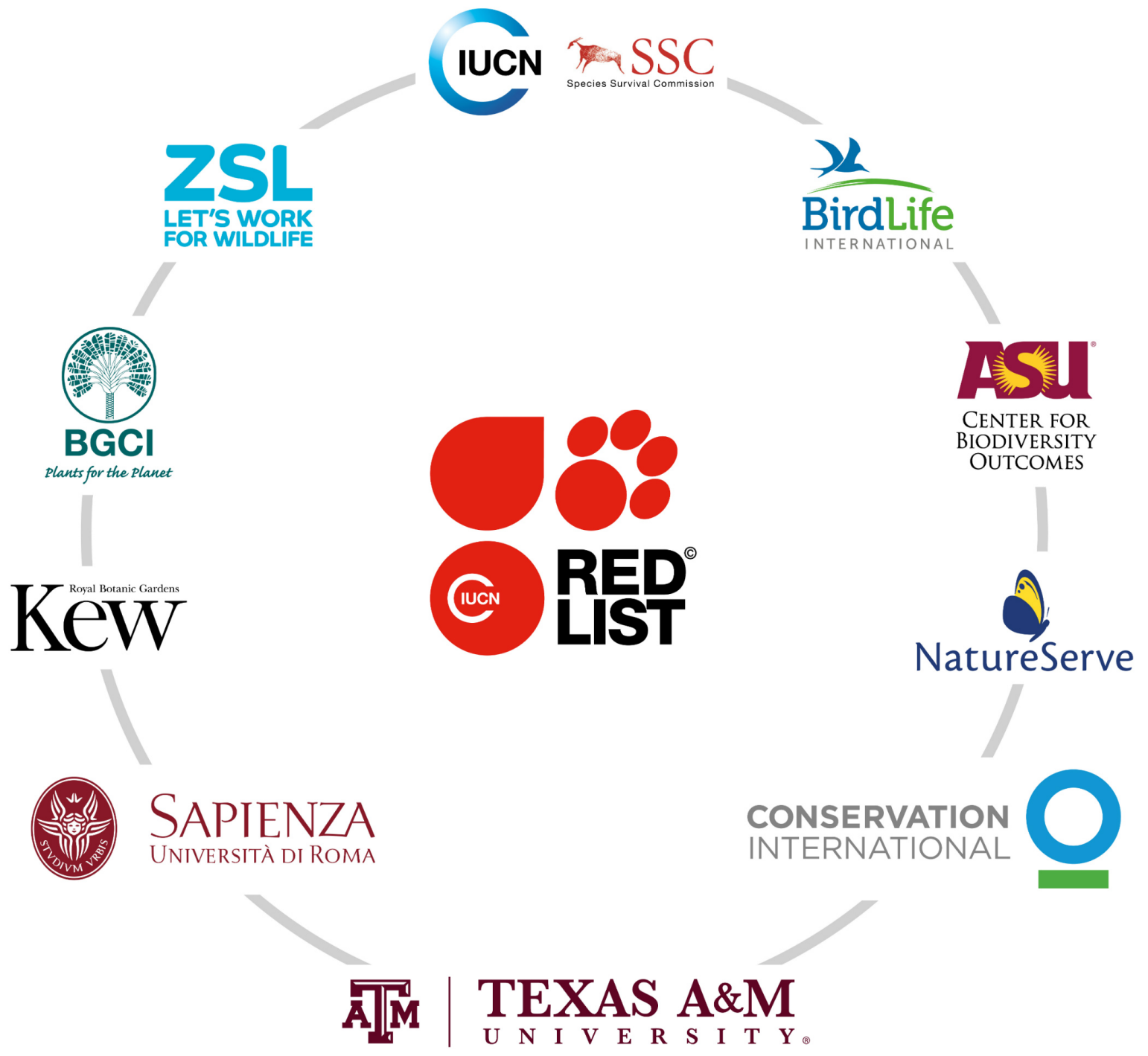

The IUCN Red List of Threatened Species ${ }^{\mathrm{TM}}$ is produced and managed by the IUCN Global Species Programme, the IUCN Species Survival Commission (SSC) and The IUCN Red List Partnership.

The IUCN Red List Partners are: Arizona State University; BirdLife International; Botanic Gardens Conservation International; Conservation International; NatureServe; Royal Botanic Gardens, Kew; Sapienza University of Rome; Texas A\&M University; and Zoological Society of London. 